\title{
Social Defence and the Psychiatric Treatment of Delinquents
}

\author{
By MARC ANCEL.
}

\begin{abstract}
Forfatteren til denne artikel er den fremstảende franske kriminalist Marc Ancel, Conseiller à la Cour de Cassation og præsident for Centre français de Droit comparé, Paris. Artiklen gengiver et foredrag, som Marc Ancel holdt i København i maj 1958 på The Seminar on the Psychiatric Treatment of Criminals and Delinquents. Efter forfatterens $\varnothing$ nske trykkes foredraget på engelsk.
\end{abstract}

The need has been felt, at this Seminar on the Psychiatric Treatment of Criminals and Deliquents, to give a hearing to the legal standpoint; for, as soon as we have to do with a delinquent, that is to say, an individual who has committed an act punishable by law - and there is no other universally accepted definition of this term - the standpoint of criminal law, which is bound to be concerned in the case, cannot be neglected. The first aim of the Seminar, moreover, is to promote the development of collaboration between doctors, the legal profession and all those concerned in the prevention and treatment of mental disorders. It is thus from the standpoint of medico-legal collaboration that the legal problems we have to face should be approached. It is, in fact, here that modern trends of thought are advancing a new concept of criminal law in the light of and in terms of the teachings of medical science, psychology, sociology, and all those sciences that have to do with criminology - that is to say all those disciplines that concern the study of criminal actions and delinquents. It is this trend of thought which has become known as social defence, a subject on which it would seem useful to go into some explanations.

There can be no question of exploring all the different aspects of social defence here, nor of expounding its special theory of criminal law. We shall confine ourselves to showing how this new doctrine may be able to provide a solution - probably the only one - to the serious problem of establishing relations between the medical and legal professions and co-operation between the Bench and the psychiatrist with a view to the proper treatment of delinquents. To gain a satisfactory understanding, we must study, in the following order: how the problem has arisen, what steps have been taken, albeit unsatisfactory to solve it and what prospects there are of finding a reasonable solution. 
I. Criminal law is much older than psychiatry. It is quite natural, therefore, that for a long time psychiatry was ignored completely by lawyers. When the criminological sciences first made their appearance in the nineteenth century, lawyers sometimes referred to them as "sciences auxiliary to criminal law"; but they still went on deliberately ignoring. True, no doubt, by then punishment was no longer inflicted on persons of unsound mind and insanity was no longer treated by thrashing or exorcism; but the criminal jurist or judge claimed that it was not their concern. Criminal law in the last century was designed for the free man, master of his every act, fully conscious of the error of his ways for which he was legally punishable. He could only escape the penalty if he was irresponsible - that is to say, incapable of understanding the implications of his act or of distinguishing between good and evil. On this point, the Code Napoléon of 1810 (Article 64) was in agreement with the principles which the famous M'Naghten rules of 1843 drew from common law.

This firm but simplistic attitude could not be maintained, however. While the French criminal code only took account of insanity, from the second half of the nineteenth century criminal jurists were obliged to take up the question of "states bordering on insanity" and big controversies arose as to the influence on criminality of epilepsy, hysteria, somnambulism, drunkenness, various forms of intoxication, deaf-muteness or lasting and temporary emotional states. While the 1867 Belgium criminal code followed the French pattern of 1810 fairly closely, the German code of 1871 tried to improve on it, and the Italian code of 1889 boldly adopted a new approach to delinquents afflicted with mental disorders.

Several years earlier, an event that was to be of considerable importance for the development of criminology had occurred in Italy: the publication of Lombroso's famous book on The Delinquent (1876). With the anthropological school, as it was then called, the criminal as an individual can be said to have burst into criminal science which, up till then, had been concerned solely with the offence, regarded as an abstract juridical concept. Indeed, the free, conscious man of 1810 , just as much as the citizen of the Declaration of Rights of 1789 , was an abstraction: a human being whose nature and motives were neither of them considered, and to be punished for the acts he committed in measured legal doses. With Lombroso, the delinquent became a concrete individual, with his tendencies and defects and above all with the marks of criminality which the new science fancied it was able to discover in advance. The first classification of delinquents sought to differentiate them by placing special emphasis on their mental abnormalities. Criminal typology in 
the first half of the twentieth century was to strengthen this standpoint, while the tremendous development of psychiatry and especially child psychiatry, which has to a great extent transformed the law in regard to juvenile delinquency - the development of psychology, with the contribution of psycho-analysis soon to follow, were to raise new problems and open up new perspectives for an adjustment of the social reaction against crime.

It may be said that between the two wars the essential elements of the problems were raised: faced with these new aspects and studies on delinquency and delinquents, what was to be the position respectively of criminology and criminal law, of the doctor and the judge, of the scientist and the jurist? The stage of "sciences auxiliary to criminal law" had already obviously been passed; but a very real conflict began to be apparent among the members of these competing disciplines. The jurist could no longer ignore the existence of criminology, but he tended to challenge the criminologist's terms of reference; for his part the criminologist dreamt of building up a form of experimental criminology which would be able to defy and, in the first place, reject as foreign to its scientific field, the standardizing dogmatics of criminal law. More patently, the day-to-day work of the criminal courts, by a series of tragi-comic events emphasized the growing opposition between psychiatrists and jurists, judges and lawyers.

At the same time, the progress of science was to raise new legal problems, particularly in criminal procedure: was it legal to use, and possible to integrate, devices such as the "lie detector", narco-anlysis and, for example, even pscycho-analysis, to penetrate, the innermost conscience of the accused. Medical ethics stepped in here to strengthen judicial — or police - ethics. The scientist's power appeared to the jurist formidable. The general question of the relation between criminal law and science medical or criminal - was assuming new significance.

It was this problem that had to be solved. An attempt had already been made, but only by means of provisional, empirical and contradictory solutions. These should, at this point, be briefly described, so that their inadequacy may be better understood.

II. For a long time a preliminary meeting between the doctor and the judge had taken place in connexion with the expert opinion, and especially the psychiatric report. One of the most frequently invoked defences in capital cases - practically speaking, in murder cases - had been based on the claim that the accused was of unsound mind. An expert was then called in to undertake a psychiatric examination. The judge, of course, was 
not bound by the expert's advice, still less so the jury, called on to give a verdict in the most serious cases. Indeed, there was never the slightest hesitancy in discussing the expert's' report, or even of bringing the appointed experts into real or apparent conflict with each other. Be that as it may, it was through the expert opinion that criminal law first came into contact with medical science.

After the early unbending attitude of criminal law had changed under the influence, moreover, of medical scientific progress, efforts were still made to meet the new needs by the old procedure of the expert examination. In taking account of states bordering on insanity, besides total insanity - of partial insanity or of mental disorders diminishing criminal responsibility without eliminating it altogether, the concept of diminished responsibility was arrived at by the end of the last century. If he was not insane, the delinquent could not be acquitted as having no responsibility for his actions; but, as his mental disorder removed a part of his responsibility, he would be less severely punished than the "normal" individual. On the continent, extenuating circumstances were the means to obtain a reduced sentence; various criminal codes at the end of the nineteenth century or at the beginning of the twentieth century expressly sanctioned this system.

The next thing was that jurists — and judges as well — sought to make use of the expert medical report to determine the amount of punishment to be meted out. The claim was made that the expert should express the proportion of responsibility in figures $(1 / 3,1 / 4,1 / 2)$ and, according to the confidence he had in the medical report, the judge would base his sentence on an arithmetical computation. But this system, too, was strangely simplistic, and was soon to raise very serious objections:

(a) doubt was soon cast on the possibility of measuring moral responsibility in terms of mental disorder — and the doctors were the first to contest this; thus the system was based on scientifically inexact premises;

(b) the reduced sentence was reproached with leaving society without protection exactly in those cases where it stood in need of added protection; semi-responsible delinquents, by the mere fact of their subnormality, were liable to remain unstable, anti-social and prone to commit misdemeanours constituting a social danger only to be combated by prolonged treatment whereas it was claimed that they could be got rid of by shorter sentences which, in fact, allowed of no treatment and, practically speaking, left them a prey to recidivism. 
It was at this stage that the jurists began to talk about social defence. Von Liszt in Germany, Stooss in Switzerland, Getz in Norway, von Hamel in the Netherlands and, particularly, Adolphe Prins in Belgium began to speak of this concept following the Italian positivists, especially Garofalo, who had clearly advanced the idea of pericolosita. Society was to be resolutely protected against the more dangerous delinquents, and these dangerous delinquents were, on the one hand, subnormal persons for whom the system of diminished responsibility was a mockery and on the other hand, offenders for whom the traditional system of aggravated sentence on a second offence proved ineffective. For both these types a bold new regime would have to be applied outside the penal provisions: one of neutralization and social protection based on the establishment of what in continental jurisprudence has been called "security measures": such as the French "relégation" or preventive detention for habitual delinquents, placement in a special mental or curative institution for subnormal offenders. The 1902 Norwegian criminal code, influenced through Getz by Stooss's project of 1893, for the first time sanctioned this dual social-defence concept: it is found again even more clearly in the famous Belgian law of 9. April 1930, specifically known as the "Social Defence Act". The important criminal codes adopted between the two wars took up the concept in their turn, among them the Danish code of 1930, the Italian code of the same year (in which Article 83 et seq. lay down, in the light of modern criminology, a series of distinctions as to "criminal responsibility" dependent upon the mental state of the subject), and the Swiss code of 1937 which boldly reintroduces the old concept of limited responsibility as determined by the medical and legal authorities through a decision reached in common.

This legislation of the thirties was thought to have solved the problem without too much difficulty thanks to what was then called the alternative choice or mixed system. Here, social defence was running a dual regime, providing for the co-existence of the traditional sentence (punishment of the crime) and the new measures, neutralization or treatment, for those for whom normal sentences were ineffective. Thus, it was fondly thought that the essential elements of classic criminal law had been maintained whilst reasonably making room for the ideas derived from positivism and advances in criminology. On the eve of the last war, this criminal legislation found a new support in the prevention of crime movement, inspired in France by the latelamented Dr Toulouse and by Professor Heuyer. This movement found expression at the International Congress of Criminology in Rome in September 1938, where it was suggested that the casefinding, isolation and treatment of individuals suffering from 
mental disorders should be undertaken with a view - once more through effective collaboration between the medical and legal authorities - to bringing about a real prevention of crime.

This development - halted by the last war — came up against a number of serious difficulties in its turn, and met with several equally serious objections:

(a) The balance struck in 1930, the much-vaunted middle road adopted by criminal legislation at that time, was more apparent than real. The criminological innovations were merely inserted into a strictly legalist system, where they constituted only limited exceptions: an attempt was made to reconcile the contradictions, but the only result was incongruous juxtaposition.

(b) The legal standpoint was dominant to the detriment of criminological criteria; purely legal distinctions and categories were misused, the cumulative system seeking to apply to a large number of delinquents at one and the same time penal and non-penal measures without being able to determine which should be applied in the first instance or differentiating in their application. Absolute and far too clear-cut distinctions were drawn between subnormal offenders on the one hand, and habitual delinquents on the other, whereas it is the habitual delinquents who are more often than not subnormal. The relation between doctors and jurists, experts and judges remained subject to the uncertainties and prejudices of the past.

(c) Last, and most important of all, this legislative movement originated in the almost instinctive desire to protect the community against dangerous individuals. The authoritarian trend in criminal law, so widespread on the eve of the last war, unfortunately strengthened this anti-individualist tendency. Hitler's Germany drew up a criminal code which sought to break loose from the traditional forms of legality in order to facilitate the tracking and punishment of offenders. In the USSR a rigorous system was introduced against "socially dangerous delinquents". Even in the United States hasty legislation ended in authorizing the internment of "psychopathic sexual delinquents" for indefinite periods under conditions which were soon to come under fire.

After the last war and the excesses of totalitarianism, a change has become necessary; the protection of society must not be sought in the limitation of guarantees protecting the individual. Human rights must be respected. The criminal code itself is only an instrument which should be adapted to the teachings of criminology, which is first and foremost a human science. It is from this that modern social defence will be born and perhaps 
solve the problem of the relation between science and the law, with which medical and legal men have been faced for nearly a century.

III. To give a complete description, or even a clear understanding of the scope of the modern social defence movement, developments outside the terms of reference of this Seminar would need to be discussed. We shall keep here to essentials, in order to return as soon as possible to the problem of medicolegal collaboration in the psychiatric treatment of delinquents.

In order to place modern social defence in its true perspective we must look at it from three different standpoints, passing from the general to the particular.

1. Originating in 1945 (with the establishment at Genoa of a Social Defence Research Centre by $\mathrm{Mr}$ Gramatica) the modern movement has from its outset been international, universalist and humanitarian. It arises from a revolt against the excesses of totalitarianism and the inroads made, particularly during the last war, on the liberty of the individual and dignity of the human person. Its purpose is, then, to restore fully the rights of man, to insist on the duties of society towards the individual, and to re-establish essential moral values in their place of honour - valid for all men and all societies - as the basis for his legal rights; in this, the new social defence differs, whether from determinist positivism, purely utilitarian eclecticism or technical legalism subservient to the interpretation of positive law.

2. Taking this as its point of departure, modern social defence seeks the rational organization of the social reaction against crime: it is therefore very definitely concerned with what continental jurists call "criminal policy". Its claim is that for three quarters of a century the reforms to which we have already referred have reflected a new tendency in this criminal policy, but that today full account should be taken of this trend, that should be accepted and the consequences arising therefrom fully grasped. The most noticeable consequences are in particular as follows:

(a) Reforms in criminal law and justice must cease to be sporadic, partial, experimentally introduced or adopted as exceptions derogatory of an otherwise sacrosanct system: the system itself must be thought out afresh in terms of the necessary reforms.

(b) The renewed system of social reaction against crime should be inspired by the two fundamental elements brought out so well by the United Nations when they included a Social Defence Section in their Organization: the prevention of crime and the treatment of delinquents. Thus, there is a clear distinction 
between the new system of criminal law and the traditional one. The latter, while waiting on the one hand until such time as an offence has been committed before it intervenes, leaves it to others to organize the prevention of crime, and on the other hand, confines itself to pronouncing vengeful sentences, indifferent alike to the effectiveness of the sanction in the case of the individual concerned and to his ultimate fate. Here, it should be remembered that, as Professor Heuyer put it "the question of the proper preventive measures to be taken in the case of mentally subnormal persons charged with offences lies at the root of social defence". Prison reform, as carried out in the principal countries, the development of the probation system and after-care, the transformation of the juvenile criminal code into a system providing for the individual and based on the observation, classification and treatment chart the course on which the new criminal policy should resolutely embark: for it must do so deliberately, and the spirit in which this is undertaken is just as important as its positive achievements.

(c) It does not follow from this that punishments should necessarily be abolished; much less that criminal justice with its procedural and legal guarantees should be abandoned. Social defence actually regards it as essential that man as an individual should know - and admit — that he must account to justice for his deeds where these are prohibited by law. But his appearance before the courts should not end either in a legal duel between the accused and the defence, nor in the automatic pronouncement of a prescribed sentence: it should be the starting point of a process of resocialization.

3. It is here that the third standpoint adopted by modern social defence emerges - the standpoint from which the necessity for co-operation between criminologists and jurists, judges and doctors becomes evident. Criminal justice — and hence the criminal code - must be renovated, both in terms of a humanist philosophy and of the requirements of the new criminal policy.

This in turn implies certain definite consequences:

(a) Modern scientific developments make it impossible for criminal law to continue living in splendid isolation. All the humanities are joining today in the study of crime and the criminal; and the differences, between those who speak of the criminal disposition - even of the criminal constitution - of criminal behaviour, the anti-social personality or the dynamics of crime can provide instructive and fruitful material for the jurist as can controversies on the classification of criminal types, the study of criminal careers or follow-up studies. Thus, criminology for the student of criminal law institutions, becomes 

equivalent to political science for the student of public insti-
tutions in the modern state.

(b) This new situation engenders a reaction against the traditional legalism. The classical jurist is too easily satisfied with the fictions and principles of abstract law and is out of touch with social and human realities. Subtle legal distinctions, the formal dualism of the cumulative system of 1930 , the complete sepato give place to from measures of treatment, must disappear which individualized system of reaction against crime in will be prescribed atreatment aimed at social rehabilitation the disciplines and carried out with the co-operation of all scientific study of the dessary specialists on the basis of a need to emphasize that concerning the prevation generous social outlook in matters in the light of the emergent crime is all the more called for State.

(c) Seen in this light, the value of collaboration between the medical profession and the courts is affirmed with redoubled emphasis. Hitherto, it has been merely a confrontation of special fields highly conscious of their opposition, whether in granted with some psychiatric examination - a necessity criminal anthropology and by the judge - or involving that research intogy, and then criminal typology. It is time in the truly modern the treatment of delinquency was pursued specialists no longer compete, but collabo which the different

It is absurd for a judge to ask an expert questions to which he can give no scientific answer; for the psychiatrist called on he would have if he had be hindered in the freedom of action the doctor called in to give deal with an ordinary patient; for be treated as an ordinary witness ation to the court or jury to up or even discredit him. agreed on the usefulness of a medical is that while everyone is tion of the offender, criminal medical and psychological examinain certain exceptional cases, an still only makes this compulsory without a proper personal, and the judge is well content to do pert under some approved forehistory. Finally, the medical exa direct collaborator with form to be determined, must become him the confidence with the judge, and the judge must accord

There can be no question of receives from the prison services. differences between the of failing to recognize the necessary psychiatrist takes his bearinger's and the judge's roles. The which often escapes all predetering an ever changing reality 
to explain the actual situation and not to pronounce any judgement as to values; the latter is precisely the role of the judge who should seek to base his decisions on clear concepts, legal definitions and established standards of conduct. While, henceforth, a man's deeds should be judged, not abstractly according to a legalist specification, but following a clear statement as to why his action was anti-social, while the offender must be brought back into the community of free men, this active policy of resicialization can only be understood where there is increasing confidence in the mutual relations of the person who can explain the individual and the person who has to decide his fate. Willynilly, that is what the modern concept of the treatment of delinquents so rich and dynamic implies; and this concept cannot really assume its full significance without the implementation of a determined social defence policy in criminal law.

Marc Ancel. 